\title{
Tips for Integrating Land and Wildlife Management: Deer in Forests ${ }^{1}$
}

\author{
William M. Giuliano, John M. Olson, and Cailey Thomas²
}

Prized by hunters and wildlife enthusiasts alike, whitetailed deer are a popular species found throughout Florida. As such, they are often the focus of management for landowners, managers, and lessees who want to improve deer populations while maintaining other land uses such as timber production.

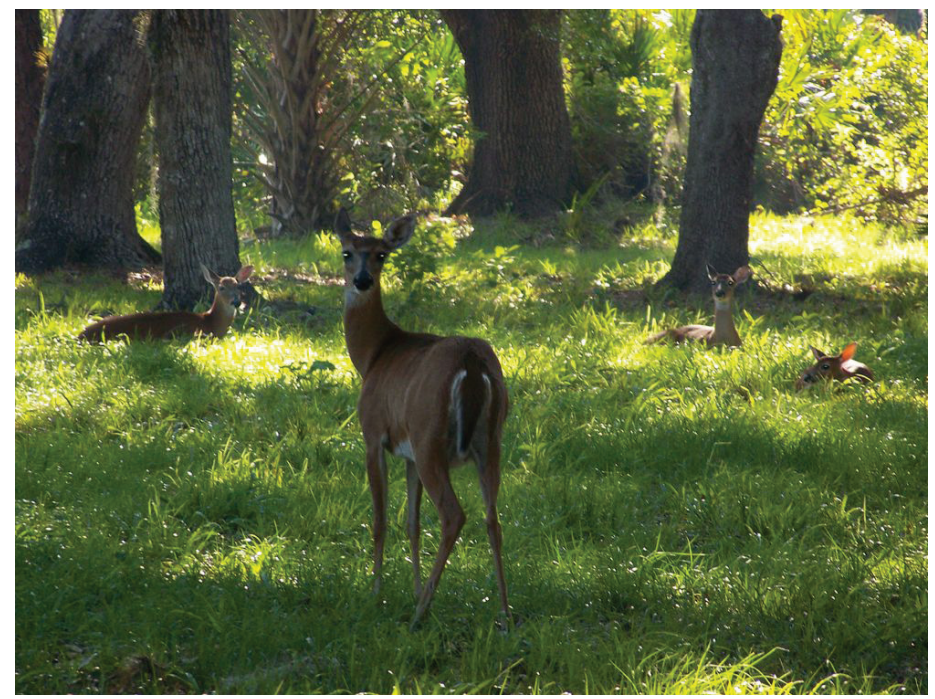

Figure 1. What often limits deer populations in Florida's forests is the availability of nutritious foods.

Credit: Tyler Mosteller

In Florida, most native habitat for deer is naturally poor, leading to relatively low deer densities and productivity, and lower-quality deer with smaller bodies and antlers. To be healthy and successful, deer need good quality food, water, and cover, and these must be distributed throughout their ranges. Water and cover are typically good and abundant in Florida forests and do not usually limit deer. However, while Florida soils support abundant growth of plants that deer eat, the foods are often of poor quality. Heavily leached and acidic soils that spend extended periods either dry or saturated retain few available nutrients for plants, resulting in deer forage that can't deliver the nutrients that permit deer to grow larger bodies and antlers or high population densities. Similarly, intensively managed forests, particularly pine plantations, which are often monotypic, provide poor deer forage.

No single plant species can provide all that a deer needs to meet its nutritional requirements. In addition to having generally low-quality foods, forests often have a low diversity of food sources, further reducing the quality of the habitat. Forest management for deer should therefore focus on providing a diversity of abundant, high-quality foods. Deer are browsers, which means that they eat mostly parts of woody plants. In order of importance, their favorite foods include the following: hard mast (such as acorns) over soft mast (such as persimmon fruit) over forbs (such as clover) over other browse (such as green briar leaves and twigs). Their least favorite foods are grasses (such as bluestem).

Florida forestlands contain a mix of habitats and land uses. It is important to manage the composition of each habitat type as well as the location of each in relation to the others

1. This document is WEC329, one of a series of the Department of Wildlife Ecology and Conservation, Florida Cooperative Extension Service, Institute of Food and Agricultural Sciences, University of Florida. Original publication date January 2013. Visit the EDIS website at http://edis.ifas.ufl.edu.

2. William M. Giuliano, professor; John M. Olson, graduate assistant; and Cailey Thomas, graduate assistant; Department of Wildlife Ecology and Conservation, University of Florida, Gainesville, FL 32611. 
in the forest to increase diversity and enhance the area for deer. Below are some deer habitat improvement tips that focus primarily on raising the quality of deer forage but that also will help you grow better cover by improving plant diversity and productivity.

\section{Tips}

- Promote hardwoods over pines in small, interspersed stands of trees of various ages (the stands should be less than 40 acres each and hardwoods should make up more than $30 \%$ of the forest).

- Encourage multiple hardwood species within and among stands to provide a more diverse and consistent mast crop.

- Use a variety of different timber harvest and forest management methods; leave some stands unharvested, especially bottomland hardwoods.

- Manage forest openings in large expanses of forest containing a mix of herbaceous and shrub species (forest openings should be from 1 to 5 acres each and take up less than $20 \%$ of the area).

- Reduce the amount of pine plantation.

- Open closed-canopy forest to allow sunlight to reach the forest floor, promoting herbaceous plant and shrub growth through thinning of trees by mechanical, chemical, or fire treatments.

- Selectively cut and remove trees to promote beneficial tree species diversity; preserve mast-producing species wherever possible.

- Disturb the soil and understory to create and maintain early successional plant communities; consider prescribed fire and roller chopping.

- Use wide spacing when artificially regenerating stands because it takes longer for the canopy to close, shade the ground, and reduce plant diversity (12-foot by 12 -foot spacing or 300 trees per acre is a good goal).

- Use coppice (stump sprouting) on hardwoods to promote browse; do not spray stumps with herbicide.

- Manage food plots of 1 - 3 acres each on at least three percent of the land to provide a mix of grasses and forbs during both cool and warm seasons.
- Use feeders to provide supplemental feed (a deer ration or chow rather than a single grain such as corn; 1 feeder will serve 30 deer or 150 acres).

- Maintain odd areas such as ditches, roadsides, corners of fields, etc., that include a diversity of plant species and structures.

These recommendations should be considered in the context of the overall forest. For example, when locating a food plot, consider putting it near a pine plantation, which has little food value for deer, rather than near a mature oak stand. An extensive discussion and descriptions of the tips provided here can be found in: Understanding White-tailed Deer: Florida and the Southeast by W.M. Giuliano, Elina Garrison, and B.J. Schad available through the UF/IFAS Extension Bookstore (http://ifasbooks.ifas.ufl.edu).

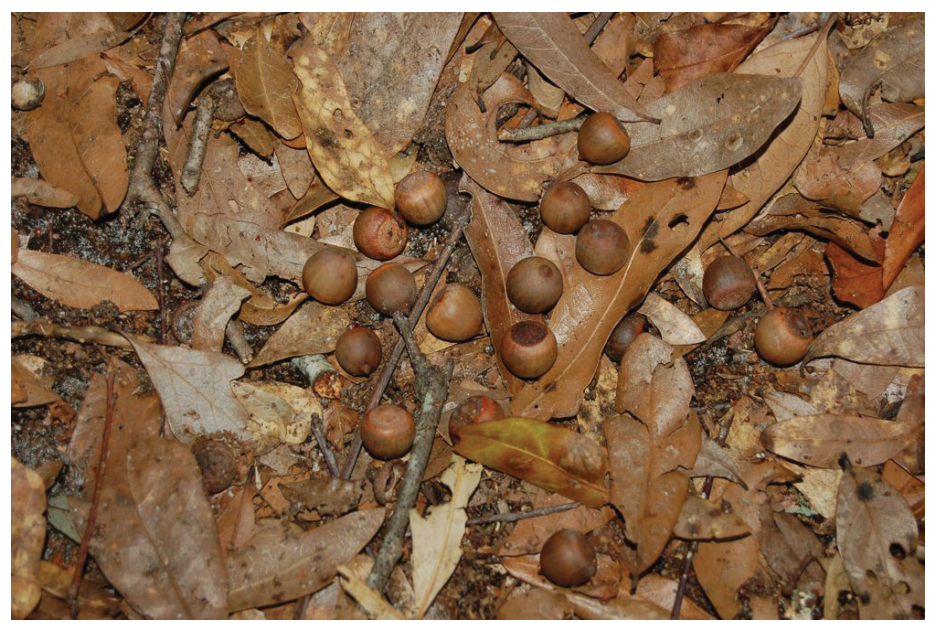

Figure 2. Deer habitat management should focus on enhancing the quantity of high quality foods such as mast (i.e., nuts, seeds, fruits, and berries).

Credit: William Giuliano 